\title{
RELEVANSI BUDAYA DAN PENDIDIKAN KRISTEN DALAM PEMBENTUKAN KARAKTER ANAK DAN PERAN MANUSIA SECARA BIOLOGIS (PENINA NIRM 2020196469)
}

\begin{abstract}
ABSTRAK
Artikel ini menggambarkan beberapa ide pemikiran terkait dengan perkembangan pendidikan kristen yang mampu membentuk karakter anak, sinkronisasi budaya Toraja dan peranan manusia (laki-laki dan perempuan) dalam pengembangan nilai-nilai kekristenan dimasyarakat. Tujuan dari pembuatan artikel ini yaitu untuk mengetahui peran pendidikan kristen terhadap pembentukan karakter anak, Untuk mengetahui sinkronisasi pendidikan kristen dan budaya masyarakat Toraja sebagai pusat peradaban kristen di Indonesia sehingga memberikan kontribusi bagi perkembangan kekristenan di Indonesia dan untuk mengetahui tendensi laki-laki dan perempuan terhadap perkembangan pendidikan kristen di masyarakat. Kata Kunci: Pendidikan, Kristen, Budaya, Toraja dan Manusia
\end{abstract}




\section{A. PENDAHULUAN}

Peradaban manusia Toraja sudah ada jauh hari sebelum datangnya institusi sekolah. Mereka tumbuh dan berkembang secara tradisional, dengan norma dan tatanan social yang melahirkan entitas budaya serta identitasnya. Budaya mereka merupakan hasil olah rasa dan karsa menjadi daya tarik bagi berbagai pihak dari luar entah untuk diteliti, maupun dalam tujuan publikasi dan dokumentasi. Kehidupan dan budaya orang Toraja tersebut menggambarkan kualitas berpikir dan kualitas hidup mereka ${ }^{1}$. Toraja juga merupakan salah satu pusat peradaban pendidikan kristen di Indonesia.

Pendidikan iman sejatinya bukan satu-satunya diperoleh melalui pendekatan sekolah formal. Fakta adalah iman lebih dominan diperoleh (dipelajari) justru melalui budaya; dan secara konkrit lebih banyak melalui keteladanan dan interelasi individual. Dengan kata lain, kepercayaan atau iman lebih dipengaruhi melalui pembentukan kultur. Pendidikan sekolah formal bukan jaminan bagi pendidikan iman ${ }^{2}$.

Salah satu hal penting dalam dunia pendidikan yang sudah lama ditinggalkan dalam pendidikan formal adalah unsur asketik. Padahal dalam budaya maupun PAK unsur asketik berupa pengendalian diri, puasa atau berpantang jelas dan nyata ada bahkan diteladankan oleh Yesus sendiri. Ensiklopedia Indonesia menuliskan bahwa askese (bahasa Junani, latihan) mula-mula tjara hidup para atlit jang teratur, djikalau mereka bersiap akan berlumba. Sekarang: tjara yang sistimatis menudju kekesempurnaan, setjara negatif dengan mematikan raga (misalnya tidak makan), setjara positif dengan memperkuat hidup rohani ${ }^{3}$.

Oleh karena itu menarik untuk dibahas lebih lanjut bagaimana peran pendidikan kristen terhadap pembentukan karakter anak? Bagaimana sinkronisasi pendidikan kristen dan budaya masyarakat Toraja sebagai pusat peradaban kristen di Indonesia sehingga memberikan kontribusi bagi perkembangan kekristenan di Indonesia? Dan terakhir bagaimana tendensi laki-laki dan perempuan terhadap perkembangan pendidikan kristen dimasyarakat?

1. Ranu Sanderan, "Heuristika dalam Pendidikan Karakter Manusia Toraja Tradisional," Jurnal Teologi dan Pendidikan Kristen Kontekstual 3 no. 2 (Desember 2020): 306

2. St,. Kartono, Menjadi Guru untuk Muridku, Penerbit Kanisius, Yogyakarta: 2001) hlm. 76-77

3. Ensiklopedia Indonesa A-E, N.V. Penerbitan W. Van Hoeve Bandung. 's-Gravenhage 


\section{B. TUJUAN DAN MANFAAT}

Tujuan dari pembuatan artiker ini yaitu:

1. Untuk mengetahui peran pendidikan kristen terhadap pembentukan karakter anak.

2. Untuk mengetahui sinkronisasi pendidikan kristen dan budaya masyarakat Toraja sebagai pusat peradaban kristen di Indonesia sehingga memberikan kontribusi bagi perkembangan kekristenan di Indonesia.

3. Untuk mengetahui tendensi laki-laki dan perempuan terhadap perkembangan pendidikan kristen dimasyarakat.

Manfaat dari pembuatan artikel ini yaitu:

1. Sebagai bahan informasi bagi masyarakat terkait peran pendidikan kristen terhadap pembentukan karakter anak.

2. Sebagai bahan informasi bagi masyarakat terkait sinkronisasi pendidikan kristen dan budaya masyarakat Toraja sebagai pusat peradaban kristen di Indonesia sehingga memberikan kontribusi bagi perkembangan kekristenan di Indonesia.

3. Sebagai bahan informasi bagi masyarakat terkait tendensi laki-laki dan perempuan terhadap perkembangan pendidikan kristen dimasyarakat. 


\section{PEMBAHASAN}

\section{Peran Pendidikan Kristen Terhadap Pembentukan Karakter Anak.}

Pendidikan sebagai sebuah proses, kini ditantang untuk dapat menginternalisasi makna dan berbagai perubahan yang mendasar menyangkut orientasi cara pandang tersebut. Untuk itu, kini amat dibutuhkan adanya transformasi pendidikan. Sekarang, pendidikan sudah harus merujuk kepada adanya kosekuensi logis dan berbagai perubahan perilaku, sikap, dan tata budaya. Bila melihat ruang hidup keagamaan dewasa ini, ternyata tidak lagi berwajah tunggal, namun sudah bersifat multifaces (berwajah banyak) ${ }^{4}$. Dengan demikian, pendidikan yang berparadigmaasketis dapat menjadi salah satu upaya transformasi alternatif menuju penumbuhan hikmat dan disiplin insani.

Kadang orang tua sering salah menafsirkan tentang lingkungan pendidikan tanpa disadari orang tua bahwa pendidikan pertama yang didapatkan seorang anak adalah lingkungan keluarga maka secara otomatif lingkungan keluarga mempunyai tanggung jawab penuh dalam pembentukan karakter anak. Anak-anak seringkali melihat bagaimana orangtua berperilaku dan selanjutnya menirunya perilaku mereka. Peneladanan perilaku akan semakin dikuatkan jika proses peniruan berlangsung secara berulang-ulang dan terus-menerus. Hampir semua orangtua akan merasa senang jika anak-anaknya meniru perilaku mereka, dan pujian bagi anak akan semakin melanggengkan proses peniruan teladan tersebut. Pujian dapat menjaga orientasi keteladanan dari anak kepada orangtua atau pemimpin yang diidolakannya, jadi setiap pemimpin, orangtua, guru atau siapapun yang digugu, sangat perlu belajar memberi pujian bagi penunutnya agar tali hubung peneladanan tetap terjalin dengan baik ${ }^{5}$.

Oleh karena itu keluarga sebagai tempat pembentukan karakater anak maka kewajiban orang tua selalu memberikan pendidikan kekristenan sedari awal. Pada sisi lain, Alkitab menekankan betapa pentingnya disiplin yang penuh kasih. Orangtua yang tidak menanamkan kedisiplinan terhadap anak remajanya, akan menghadapi akibat-akibat yang dapat menyakitkan dikemudian hari, baik pada diri orang tua maupun pada diri anak itu sendiri. Penanaman nilai disiplin tentu perlu menyesuaikan dengan perkembangan serta usia anak dan tanpa memaksakan kehendak pribadinya. Bagi anak kecil, sikap orangtua yang relatif ketat amatlah tepat. Tetapi terhadap anak yang sudah memasuki usia remaja sudah perlu dibimbing untuk mengambil keputusannya sendiri. Ronald W. Leigh, mengatakan: kebebasan remaja sampai pada taraf tertentu harus dipandang sebagai suatu hal yang positif. Apabila remaja tidak belajar mengambil keputusannya sendiri, maka ia akan lambat menjadi dewasa ${ }^{6}$, demikian sebaliknya. Jadi penerapan disiplin dalam diri seorang anak sesungguhnya

4. Lih.http://www.imankatolik.or.id/katekese dan avant gardist

5. Rannu Sanderan, "Exemplary Menemukali Kunci Pendidikan Iman Bagi Anak Dalam Keluarga dan Disekolah". STAKN Toraja, 2016.

6. Ronald W. Leigh, Melayani Dengan Efektif, (Jakarta: BPK. Gunung Mulia, 1996) cet. 3, hlm. 118 
merupakan pola pendidikan exemplaris (meta-model); dimana sang anak sendiri akan menirukan pola disiplin yang sama pada keturunannya atau generasi pelanjutnya kelak.

\section{Sinkronisasi Pendidikan Kristen Dan Budaya Masyarakat Toraja Sebagai Pusat}

\section{Peradaban Kristen Di Indonesia Sehingga Memberikan Kontribusi Bagi}

\section{Perkembangan Kekristenan Di Indonesia.}

Pendidikan kristen seyogyanya sangat berkaitan erat dengan kebudayaan masyarakat Toraja hal ini bisa dijumpai dikalangan masyarakat ketika masyarakat mendengar nama Toraja maka secara otomatis terlintas dipikiran mereka bahwa itu adalah kristen, sementara yang seharusnya terbayang dipikiran mereka ketika menyebut gereja maka seharusnya pemikiran kristenlah yang harus melekat karena gereja adalah tempat ibadah bukanlah Toraja karena toraja hanyalah salah satu etnis di Indonesia. Tentunya pandangan itu bukan sesuatu yang tidak berdasar.

Pada masa dulu gereja Toraja sendiri sebagai stakeholder terbesar, memakai Tongkongan sebagai simbolisasi persekutuan pada jenjang sinodal, yakni Tongkonan Sangulele. Untuk menolong pembaca melihat prinsip dan hakikat keberadaan tongkonan tersebut maka di bawah ini hendak diurai dimensi ekklesia dari tongkonan hingga fungsinya sebagai media transmisi nilai lintas generasi ${ }^{7}$. Realitas sosial dan fenomena empirik yang terlihat secara langsung sehubungan dengan budaya orang Toraja adalah simbol sosial kemasyarakatan terkecil yakni rumah. Rumah dalam arti sempit, yaitu Tongkonan merupakan konstruksi budaya (fisikal belaka) yang didirikan oleh nenek moyang mereka ${ }^{8}$. Dari kebudayaan tongkonan inilah awal mulanya Toraja menkontribusikan budayanya dalam perkembangan kekristenan di Indonesia.

\section{Tendensi Laki-Laki Dan Perempuan Terhadap Pendidikan Kristen Di Mayarakat}

Alasan klasik yang sering muncul ketika membandingkan antara laki-laki dan perempuan yaitu laki-laki berfikir dan bertindak mengutamakan logika/analisa sedangkan perempuan mengutamakan perasaan atau berdasarkan rasa nyaman atau tidak nyaman. Hal inilah yang kemudian mendiskriminasi perempuan dalam mengajarkan tentang pendidikan kekritstenan dimasyarakat akan tetapi anggapan demikian tentunya bukan tanpa alasan.

Alasan budaya (kebiasaan-red) memengaruhi perbedaan peranan laki-laki dan perempuan dalam pelayanan jemaat. Internalisasi nilai budaya (Toraja) yang menempatkan laki-laki sebagai pengayom perempuan, tereksternalisasi secara bias dalam praktik berbudaya; dimana laki-laki dan perempuan dipandang secara dikotomis: laki-laki untuk urusan publik, perempuan untuk urusan domestik. Konsekuensinya ialah laki-laki dinilai lebih utama daripada perempuan. Untuk berbagai peran publik, misalnya dalam pelayanan

7. Theodorus Kobong, Injil dan Tongkonan: inkarnasi, kontekstualisasi, transformasi (Jakarta: BPK Gunung Mulia, 2008). 86-89

8. L. T. Tangdilintin, Toraja Dan Kebudayaannya (Tana Toraja: Yayasan Lepongan Bulan, 1975). 116 
jemaat, ungkapan "jika masih ada laki-laki, kenapa harus perempuan" masih demikian melekat dalam diri baik laki-laki maupun perempuan? .

Dengan demikian sudah bisa diketahui bahwa tendesi laki-laki jauh lebih besar dibandingkan dengan perempuan terhadap pendidikan kristen dimasyarakat karena sejatinya perbedaan laki-laki dengan perempuan selalu dilihat dalam kaitannya dengan kejatuhan manusia kedalam dosa, seperti perempuan itulah yang tergoda dan jatuh ke dalam dosa. (1 Tim. 2:1 1-14). Bahkan dengan lebih tegas lagi dijelaskan bahwa perempuan tidak diizinkan untuk mengajar laki-laki hendaknya perempuan berdiam diri dalam persekutuan.

9. Rannu Sanderan, “Jabatan Gerejawi dan Pelayanan Perempuan Dalam Pelayanan Gereja”. STAKN Toraja. 


\section{KESIMPULAN DAN SARAN}

\section{Kesimpulan}

Berdasarkan pembahasan diatas dapat disimpulkan:

a. Keluarga sebagai tempat pembentukan karakater anak maka kewajiban orang tua selalu memberikan pendidikan kekristenan sedari awal. Pada sisi lain, Alkitab menekankan betapa pentingnya disiplin yang penuh kasih. Orangtua yang tidak menanamkan kedisiplinan terhadap anak remajanya, akan menghadapi akibat-akibat yang dapat menyakitkan dikemudian hari, baik pada diri orang tua maupun pada diri anak itu sendiri.

b. Tongkonan sebagai rumah budaya yang dijadikan masyarakat sebagai tempat belajar pertama kali tentang ilmu-ilmu kekristenan sehingga dari kebudayaan tongkonan inilah awal mulanya Toraja menkontribusikan budayanya dalam perkembangan kekristenan di Indonesia.

c. Tendesi laki-laki jauh lebih besar dibandingkan dengan perempuan terhadap pendidikan kristen dimasyarakat karena sejatinya perbedaan laki-laki dengan perempuan selalu dilihat dalam kaitannya dengan kejatuhan manusia kedalam dosa sebagaiman mana yang dijelaskan dalam alkitab.

\section{Saran}

Artikel ini masih jauh dari kata sempurna oleh karenanya diharapkan kritikan yang bersifat konstruktif dari pembaca. 


\section{DAFTAR PUSTAKA}

Ensiklopedia Indonesa A-E, N.V. Penerbitan W. Van Hoeve Bandung. 's-Gravenhage

Kartono, ST. Menjadi Guru untuk Muridku, Penerbit Kanisius, Yogyakarta: 2001) hlm. 76-77

Kobong, Theodorus. Injil dan Tongkonan: inkarnasi, kontekstualisasi, transformasi (Jakarta: BPK Gunung Mulia, 2008). 86-89

Leigh, Ronald W. Melayani Dengan Efektif, (Jakarta: BPK. Gunung Mulia, 1996) cet. 3, hlm. 118

Lih.http://www.imankatolik.or.id/katekese dan avant gardist

Sanderan, Ranu. "Exemplary Menemukali Kunci Pendidikan Iman Bagi Anak Dalam Keluarga dan Disekolah”. STAKN Toraja, 2016.

---------------. "Heuristika dalam Pendidikan Karakter Manusia Toraja Tradisional," Jurnal Teologi dan Pendidikan Kristen Kontekstual 3 no. 2 (Desember 2020): 306

-------------. "Jabatan Gerejawi dan Pelayanan Perempuan Dalam Pelayanan Gereja". STAKN Toraja

Tangdilintin, L. T. Toraja Dan Kebudayaannya (Tana Toraja: Yayasan Lepongan Bulan, 1975). 116 